\title{
UJI AKTIVITAS ANTIDIARE FRAKSI ETIL ASETAT BUAH LIBO (FICUS VARIEGATA BLUME) PADA MENCIT (MUS MUSCULUS)
}

\author{
Utari Sugipratiwi, Vina Maulidya, Rolan Rusli \\ Laboratorium Penelitian dan Pengembangan Farmaka Tropis \\ Fakultas Farmasi Universitas Mulawarman \\ *email: Utarisugipratiwi@gmail.com
}

\begin{abstract}
Libo (ficus variegata blume) have benefits because it contains active compound of flavonoid. Flavanoid could inhibited activation of intestine peristaltic, so that could hinder defecation frequency, decreasing the secretion of fluids and electrolytes. The aims of this research was to understand activity of ethyl acetate fraction of libo fruit as an antidiarrheal in mice (mus musculus). Diarrheal condition was made with induction use oleum ricini (castor oil). Methods used is protection method for castor oil. The results show that ethyl acetate faction of libo fruit was have antidiarrheal activity.
\end{abstract}

Keywords: Antidiarrheal, Ficus variegata Blume, Oleum ricini

\begin{abstract}
ABSTRAK
Tumbuhan libo bermanfaat sebagai obat karena mengandung senyawa aktif golongan flavonoid. Flavanoid dapat menghambat gerakan peristaltik usus sehingga dapat menghambat frekuensi defekasi, mengurangi sekresi cairan dan elektrolit. Penelitian ini bertujuan untuk mengetahui aktivitas fraksi etil asetat buah libo (Ficus variegata Blume) sebagai antidiare pada mencit (Mus musculus). Untuk memberikan kondisi diare, hewan coba diinduksi oleum ricini (minyak jarak) secara oral. Metode yang digunakan adalah metode proteksi terhadap minyak jarak. Hasil yang diperoleh menunjukkan bahwa fraksi etil asetat buah libo memiliki aktivitas sebagai antidiare.
\end{abstract}

Kata Kunci: Antidiare, Ficus variegate Blume, oleum ricini

\section{PENDAHULUAN}

Libo (ficus variegata blume) merupakan salah satu jenis dari marga Moraceae yang penyebarannya meliputi seluruh Asia Tenggara, India, Jepang, Cina, Taiwan, Australia, Kepulauan Pasifik [1]. Biasanya buah libo digunakan oleh masyarakat sebagai obat diare dan obat eksim. Pada penelitian sebelumnya oleh Rijai (2013) menyatakan bahwa buah libo memiliki kaitannya dengan potensi kefarmasian dan terbukti berpotensi sebagai sumber bahan antioksidan, sitotoksik atau antikanker, pembasmi larva A. aegypti, dan sebagai antibakteri [2]. Kandungan senyawa buah libo pada fraksi etil asetat adalah flavonoid, alkaloid, dan steroid/triterpenoid [3].

Diare adalah peningkatan frekuensi dan penurunan konsistensi dari feses bildibandingkan dengan individu yang normal, dengan kata lain diare adalah buang air besar lembek atau cair yang terjadi sebanyak tiga kali atau lebih dalam waktu 24 jam [4]. Secara umum diare dapat terjadi karena meningkatnya peristaltik usus dan gangguan absorbsi sehingga tinja menjadi encer, sehingga diperlukan obat yang dapat menurunkan peristaltik usus yang dapat meurunkan usus dan yang dapat mengentalkan tinja.

Berdasarkan uraian diatas, maka dilakukan penelitian uji aktivitas antidiare fraksi etil asetat buah libo untuk mengetahui apakah buah libo mempunyai aktivitas sebagai antidiare secara in vivo pada mencit. 


\section{METODE PENELITIAN}

\section{Alat dan Bahan Penelitian}

Alat yang digunakan meliputi oven, mortar, stamper, timbangan analitik (prescisa XB 220A), Rotary Evaporator (Butchi), destilator, waterbath, hot plate, alat-alat kaca, sonde oral, desikator, stopwatch, dan kandang hewan uji.

Bahan yang digunakan meliputi Buah libo (ficus variegata Blume) yang diambil adalah buah yang masih segar dan sudah tua, hewan uji yang digunakan adalah mencit betina umur 2-3 bulan. Pelarut yang digunakan n-heksan, metanol (teknis), dan etil asetat. Bahan lain yang digunakan dalam uji aktivitas antidiare buah libo adalah loperamide $\mathrm{HCl}$, air suling, CMC 1\%, kertas saring, dan castor oil (oleum ricini).

\section{Prosedur Kerja}

Simplisia buah libo diekstraksi dengan menggunakan metode maserasi dengan pelarut n-heksan lalu dilanjutkan dengan menggunakan pelarut metanol. Kemudian dilakukan fraksinasi terhadap ekstrak metanol buah libo dengan menggunakan etil asetat (Ningsih, 2016).

Pengujian aktivitas antidiare fraksi etil asetat buah libo diuji dengan metode proteksi diare yang diinduksi oleh oleum ricini. Pertama mencit dipuasakan selama satu jam sebelum pengujian dimulai. Tiap mencit diberi $0,5 \mathrm{ml}$ oleum ricini. selanjutnya Mencit ditempatkan di dalam bejana individual yang beralaskan kertas saring pengamatan yang terlebih dahulu di timbang. Satu jam setelah diinduksi tiap mencit diberi perlakuan. Respon yang terjadi pada mencit diamati selang waktu 30 menit.

\section{HASIL DAN PEMBAHASAN}

Pengujian efek antidiare ini menggunakan metode proteksi. Metode proteksi diare digunakan Oleum ricini sebagai penginduksinya. Oleum ricini merupakan trigliserida dari asam risinoleat yang dapat terhidrolisis dalam usus oleh lipase menjadi gliserin dan asam risinoleat. Sebagai surfaktan anionik zat ini bekerja mengurangi absorpsi neto cairan dan elektrolit serta menstimulasi peristaltik usus, sehingga Oleum ricini dapat menyebabkan diare. Parameter yang diamati adalah frekuensi diare, bobot feses, konsistensi feses, waktu timbul diare dan lama diare.

Tabel. 1 Data berat feses fraksi etil asetat buah libo

\begin{tabular}{ccccccccccc}
\hline Kelompok & \multicolumn{10}{c}{ Berat feses pada menit ke- } \\
\cline { 2 - 11 } uji & 30 & 60 & 90 & 120 & 150 & 180 & 210 & 240 & 270 & 300 \\
\hline CMC 1\% & 0 & 2,6803 & 0,5402 & 0,2138 & 0 & 0,4202 & 0 & 0,0456 & 0 & 0,0045 \\
Loperamid & 0 & 0 & 0 & 1,1305 & 0,4637 & 0,3405 & 0 & 0 & 0,5403 & 0 \\
$10 \mathrm{mg} / \mathrm{kg} \mathrm{BB}$ & 0 & 0,4016 & 0,2419 & 0 & 0,0429 & 0,2887 & 0 & 0,0764 & 0,01 & 0 \\
$40 \mathrm{mg} / \mathrm{kg} \mathrm{BB}$ & 0 & 0 & 0 & 0,4787 & 0,1845 & 0 & 0 & 0,1101 & 0,012 & 0 \\
$100 \mathrm{mg} / \mathrm{kg} \mathrm{BB}$ & 0 & 0 & 0,0694 & 0 & 0,6498 & 0,5893 & 0 & 0,1148 & 0,0679 & 0 \\
\hline
\end{tabular}

Tabel. 2 Data konsistensi feses fraksi etil asetat buah libo

\begin{tabular}{ccccccccccc}
\hline \multirow{2}{*}{ Kelompok uji } & \multicolumn{10}{c}{ Konsistensi feses pada menit ke- } \\
\cline { 2 - 12 } & 30 & 60 & 90 & 120 & 150 & 180 & 210 & 240 & 270 & 300 \\
\hline CMC 1\% & 0 & 4 & 4 & 4 & 0 & 4 & 0 & 4 & 0 & 3 \\
Loperamid & 0 & 0 & 0 & 4 & 4 & 4 & 0 & 0 & 1 & 0 \\
$10 \mathrm{mg} / \mathrm{kg} \mathrm{BB}$ & 0 & 4 & 4 & 0 & 3 & 4 & 0 & 3 & 3 & 0 \\
$40 \mathrm{mg} / \mathrm{kg} \mathrm{BB}$ & 0 & 0 & 0 & 2 & 2 & 0 & 0 & 2 & 3 & 0 \\
$100 \mathrm{mg} / \mathrm{kg} \mathrm{BB}$ & 0 & 0 & 2 & 0 & 4 & 2 & 0 & 4 & 2 & 0 \\
\hline
\end{tabular}


Parameter pertama yang diamati pada metode proteksi diare yang diinduksi oleh Oleum ricini adalah bobot feses yang dapat dilihat pada Tabel 1. Hasil penelitian menunjukan bahwa berat feses pada kontrol negatif lebih besar dibandingkan kontrol positif dan dosis uji terutama pada menit ke 60, menit ke 90 dan menit ke 300. Pada menit ke 300 sudah berhenti berdefekasi. Kemungkinan hal ini terjadi karena dosis oleum ricini yang terdapat dalam tubuh mencit sudah habis bereaksi sehingga usus halus pada mencit tidak terangsang lagi untuk berdefekasi.

Parameter kedua yang diamati pada metode proteksi diare yang diinduksi oleh Oleum ricini adalah konsistensi feses yang dapat dilihat pada Tabel 2. Konsistensi feses dikategorikan menjadi 5 yaitu tidak BAB (0), normal (1), padat lembek (2), lembek cair (3) dan cair/berlendir (4). Dinyatakan memiliki efek antidiare adalah yang menunjukkan angka konsistensi paling kecil. Hasil penelitian menunjukan bahwa feses yang lembek memiliki massa yang lebih berat dibandingkan dengan feses normal. Pada dosis $10 \mathrm{mg} / \mathrm{kg} \mathrm{BB}$ memperbaiki konsistensi feses pada menit ke 150 sampai menit ke 270 dibandingkan kelompok kontrol. Sedangkan dosis $100 \mathrm{mg} / \mathrm{kg}$ BB memperbaiki konsistensi feses pada menit ke 180 sampai menit ke 270 dibandingkan kelompok kontrol dan DM dosis $590 \mathrm{mg} / \mathrm{kg}$ bb. Pada kontrol positif di menit ke 90 belum mengalami defekasi, pada menit ke 120 hingga menit ke 180 barulah mencit mengalami peningkatan defekasi dengan konsistensi 4 (cair/lendir).

Parameter ketiga yang diamati pada metode proteksi diare yang diinduksi oleh Oleum ricini adalah waktu timbul diare yang dapat dilihat pada Gambar 1 . Hasil penelitian menunjukan bahwa pengaruh dari oleum ricini terhadap respon diare pada setiap mencit memiliki waktu diare yang berbeda yaitu sekitar 60 sampai 180 menit. Diduga karena masing-masing mencit masih memiliki cadangan makanan di dalam tubuh yang berbedabeda. Dan dari hasil yang diperoleh menunjukkan dengan semakin cepat terjadinya diare maka efek antidiare akan semakin lemah.

Parameter keempat yang diamati pada metode proteksi diare yang diinduksi oleh Oleum ricini adalah durasi diare yang dapat dilihat pada Gambar 2. Hasil penelitian menunjukan bahwa dosis $40 \mathrm{mg} / \mathrm{kg}$ BB dan $100 \mathrm{mg} / \mathrm{kg}$ BB menurunkan durasi diare dibandingkan dengan kontrol. Kontrol positif menunjukkan waktu yang paling lama diduga karena CMC yang diberikan tidak dapat bekerja untuk mengkondisikan dehidrasi dan mengembalikan keseimbangan elektrolit dalam usus.

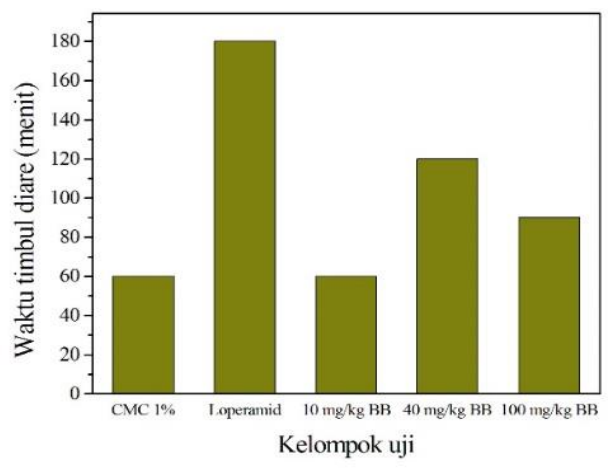

Gambar 1. Diagram batang waktu timbul diare fraksi etil asetat buah libo 


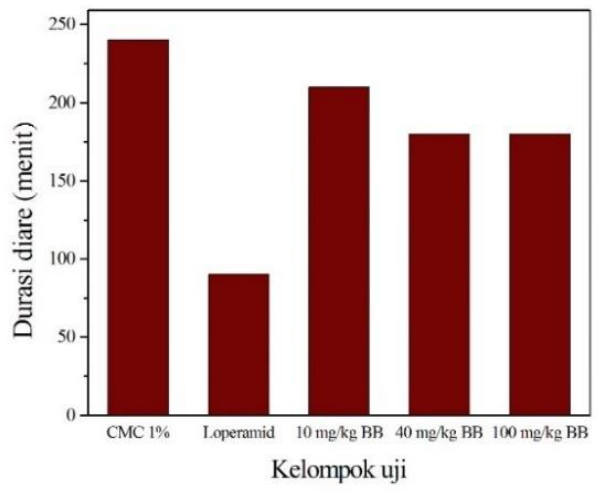

Gambar 2. Diagram batang durasi diare fraksi etil asetat buah libo

Hasil penapisan fitokimia dari Kandungan senyawa buah libo pada fraksi etil asetat adalah flavonoid, alkaloid, dan steroid/triterpenoid [3]. Beberapa penelitian telah melaporkan mengenai flavonoid sebagai antidiare karena mekanisme flavonoid dalam menghentikan diare yang diinduksi oleh oleum ricini adalah dengan menghambat motilitas usus sehingga mengurangi sekresi cairan dan elektrolit [5]. Aktivitas flavonoid yang lain adalah dengan menghambat pelepasan asetilkolin di saluran cerna [6]. Penghambatan pelepasan asetilkolin akan menyebabkan berkurangnya aktivasi reseptor asetilkolin nikotinik yang memperantarai terjadinya kontraksi otot polos dan teraktivasinya reseptor asetilkolin muskarinik (khususnya Ach-M3) yang mengatur motilitas gastrointestinal dan kontraksi otot polos [7].

\section{KESIMPULAN}

Berdasarkan hasil pengamatan frekuensi diare, bobot feses, konsistensi feses, waktu timbul diare dan durasi diare fraksi etil asetat buah libo memiliki efek antidiare.

\section{DAFTAR PUSTAKA}

1. Zhekun, Z and M.G. Gilbert. 2003. Moraceae. Flora of China 5: 21-73.

2. Rijai, L., 2013. Potensi Tumbuhan Libo (Ficus variegata Blume.) Sebagai Sumber Bahan Farmasi Potensial. Journal of Tropical Pharmacy and Chemistry, 2. (3). 166-179. DOI: https://doi.org/10.25026/jtpc.v2i3.63

3. Ningsih, B., Rahmadani, A., Fadraersada, J., \& Rusli, R. (2016). AKTIVITAS ANTIBAKTERI DAN ANTIOKSIDAN ISOLAT FRAKSI ETIL ASETAT BUAH LIBO (Ficus variegata Blume.). Prosiding Seminar Nasional Tumbuhan Obat Indonesia Ke-50. http://prosiding.farmasi.unmul.ac.id/index.php/mpc/article/view/95 
4. Dipiro, J.T., Talbert, R. L., Yee, G. C., Matzke, G. R., Wells, B. G., Posay. L. M. 2006. Pharmacotherapi Handbook, 6th Edition. McGraw-Hill.

5. Di Carlo, G., Autore, G., Izzo, A.A., Maiolino, P., Mascolo, N., Viola, P., Diurno, M.V., and Capasso, F. 1993. Inhibition of Intestinal Motility and Secretory by Flavonoids in Mice and Rats: Structure Activity Relationships. Journal of Pharmacy and Pharmacology. 45 (12): 1054-1059.

6. Lutterodt, G.D. 1989. Inhibition of Gastrointestinal Release of Acetylcholine by Quercetin as a Possible Mode of Action of Psidium guajara leaf Extracts in the Treatment of Acute Diarrhoea Disease. Journal Ethnopharmacology. 23: 235-247.

7. Ikawati, Z. 2008. Pengantar Farmakologi Molekuler. Gadjah Mada University Press, Yogyakarta. 